\title{
In Vitro Antischistosomal Activity and Cytotoxicity of 5-Methoxylated Flavones fom Vochysia divergens, a Flood-Adapted Species from Brazilian Pantanal
}

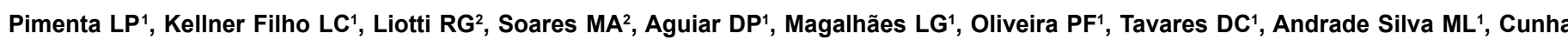
WR ${ }^{1}$, Pauletti $\mathbf{P M}^{1}$ and Januario $\mathrm{AH}^{1 *}$

${ }^{1}$ Núcleo de Pesquisas em Ciências Exatas e Tecnológicas, Universidade de Franca, Franca-São Paulo, Brazil

${ }^{2}$ Laboratório de Biotecnologia e Ecologia Microbiana, Departamento de Botânica e Ecologia, Universidade Federal de Mato Grosso, Cuiabá-Mato Grosso, Brazil

\begin{abstract}
Background: Vochysia divergens is native to the Amazon Basin and considered an invasive species in the Brazilian Pantanal. In this work, the ethanolic extract of V. divergens leaves was chemically investigated and evaluated in vitro against Schistosoma mansoni adult worms together with the isolated compounds.

Methods: The samples were available at concentrations of $12.5,25,50$ and $100 \mu \mathrm{M}$. The parasites were kept for 4 days and monitored every $24 \mathrm{~h}$ to evaluate their viability and motor activity comparing with the positive control praziquantel. The cell viability of isolated flavones as determined by XTT assays in V79 cells.

Results: The flavones 3',5-dimethoxy luteolin-7-O- $\beta$-glucopyranoside, 5-methoxy luteolin and 3',5-dimethoxy luteolin were isolated from V. divergens. Flavone 5-methoxy luteolin caused the death of $25 \%$ of male and female adult S. mansoni worms in $24 \mathrm{~h}$ at $100 \mu \mathrm{M}$ and also reduced their motor activity. Flavones 3',5-dimethoxy luteolin$7-O-\beta$-glucopyranoside and 3',5-dimethoxy luteolin were able to slightly reduce the motor activity to $25 \%$ within 24 h at $25 \mu \mathrm{g} / \mathrm{mL}$ and $12.5 \mu \mathrm{g} / \mathrm{mL}$, respectively, but only in male worms. The results were compared with the flavone luteolin. For XTT assay in V79 cells the IC50 values were $1468.4 \pm 10.5 \mu \mathrm{M}, 5946.6 \pm 25,1 \mu \mathrm{M},>7960.8 \mu \mathrm{M}$ and $270.6 \pm 9.3 \mu \mathrm{M}$ for compounds 3',5-dimethoxy luteolin-7-O- $\beta$-glucopyranoside, 5-methoxy luteolin, 3',5-dimethoxy luteolin and luteolin, respectively.
\end{abstract}

Conclusion: To the best of our knowledge, flavones 5-methoxy luteolin and 3',5-dimethoxy luteolin are reported for the first time as constituents of $\mathrm{V}$. divergens and the Vochysiaceae family.

Keywords: Vochysia divergens; Vochysiaceae; Flavones; Schistosomicidal activity

\section{Introduction}

Vochysia divergens Pohl (Vochysiaceae), commonly known as Cambará, is native to the Amazon Basin and considered an invasive species in the wetlands of the Brazilian Pantanal. Vochysia divergens has wide tolerance for seasonal variations in hydrology, allowing it to endure seasonal drought during the dry season and seasonal flooding during the wet season in the Pantanal [1].

The chemical constituents of Vochysia genus include ellagic acid derivatives, flavonoids, steroids and acid triterpenoids [2].

$V$. divergens is used in folk medicine against infectious diseases and asthma. The antibacterial activity of the ethanolic extract of $V$ divergens stem bark has been evaluated against Escherichia coli and Staphylococcus aureus with MIC $>5$ and $1.5 \mathrm{mg} / \mathrm{mL}$, respectively [3]; however, the potential schistosomicidal of this species remains unknown.

Schistosomiasis, which is caused by trematode flatworms of the genus Schistosoma, is one of the most significant and neglected tropical diseases in the world. This disease has significant prevalence and morbidity, affecting more than 207 million people worldwide and resulting in as many as 280,000 deaths each year. Moreover, there are almost 800 million people who are at risk of infection despite the great advances in its treatment and prevention [4-6].

Praziquantel and oxamniquine are the drugs that are currently available for the treatment of schistosomiasis. Praziquantel does not prevent re-infection and is inactive against juvenile schistosomes. Furthermore, it has a limited effect on existing lesions in the liver and spleen [7].
Low cure rates and treatment failure following praziquantel administration together with the existence of resistant strains reinforces the need to develop new safe and effective schistosomicidal agents $[8,9]$. As part of our advancing investigation on the schistosomicidal activity of Brazilian species from "Cerrado" and "Pantanal" [10-12], the present work reports on the in vitro schistosomicidal activity of the ethanolic extract and three isolated 5-methoxy-flavones from $V$. divergens leaves.

\section{Materials and Methods}

\section{General}

${ }^{1} \mathrm{H}$ and ${ }^{13} \mathrm{C}$ NMR spectra were recorded in methanol- $d_{4}$ for compounds $\mathbf{1}$ and $\mathbf{2}$ and in pyridine- $d_{5}$ for compound $\mathbf{3}$ on a Bruker ${ }^{\oplus}$ DRX-400 and Bruker ${ }^{\infty}$ DRX-500 spectrometer using TMS as the internal standard.

The analytical HPLC separation analyses were carried out on a Shimadzu Prominence LC-20AD binary system equipped with a DGU-20A5 degasser, a SPD-20A series diode array detector, a CBM-

*Corresponding author: Januario $\mathrm{AH}$, Núcleo de Pesquisas em Ciências Exatas e Tecnológicas, Universidade de Franca, Av. Armando Salles Oliveira, 201, Franca, São Paulo, Brazil, Tel: + 5516 37118871; E-mail: anahjanuario@gmail.com

Received April 30, 2015; Accepted May 11, 2015; Published May 13, 2015

Citation: Pimenta LP, Kellner Filho LC, Liotti RG, Soares MA, Aguiar DP et al. (2015) In Vitro Antischistosomal Activity and Cytotoxicity of 5-Methoxylated Flavones fom Vochysia divergens, a Flood-Adapted Species from Brazilian Pantanal. Adv Pharmacoepidemiol Drug Saf 4: 182. doi:10.4172/2167-1052.1000182

Copyright: (c) 2015 Pimenta LP, et al. This is an open-access article distributed under the terms of the Creative Commons Attribution License, which permits unrestricted use, distribution, and reproduction in any medium, provided the original author and source are credited. 
Citation: Pimenta LP, Kellner Filho LC, Liotti RG, Soares MA, Aguiar DP et al. (2015) In Vitro Antischistosomal Activity and Cytotoxicity of 5-Methoxylated Flavones fom Vochysia divergens, a Flood-Adapted Species from Brazilian Pantanal. Adv Pharmacoepidemiol Drug Saf 4: 182. doi:10.4172/2167-1052.1000182

Page 2 of 5

20A communication bus module, an SIL-20A HT autosampler, and a CTO-20A column oven.

The preparative HPLC separation step was carried out on a Shimadzu LC-6AD system equipped with a DGU-20A5 degasser, a SPD-20A series UV-VIS detector, a CBM-20A communication bus module, and a Reodyne manual injector. Separation of the micromolecules was accomplished on a Shimadzu Shim-pack ODS columns (particle diameter $5 \mu \mathrm{m}, 250 \times 4.6 \mathrm{~mm}$, and $250 \times 20 \mathrm{~mm}$ ) equipped with a pre-column of the same material.

The $\mathrm{MeOH}$ used in the experiments was HPLC grade and was obtained from J. T. Baker. Ultrapure water was obtained by passing redistilled water through a Direct-Q UV3 system from Millipore. Luteolin L9283 $(\geq 98,9 \%)$ was purchased from Sigma-Aldrich (St. Louis, MO.)

\section{Plant material}

Vochysia divergens was collected in the Pantanal Mato-grossense region $\left(\mathrm{S} 16^{\circ} 35^{\prime} 22,90^{\prime \prime}\right.$ and W56 $\left.47^{\prime} 83,40^{\prime \prime}\right)$ in October 2012. A voucher specimen, UFMT 39559, was deposited in the Herbarium of Federal University of Mato Grosso, UFMT, Brazil (Herbarium UFMT).

\section{Extraction and isolation of flavones}

The air-dried leaves of $V$. divergens $(1.27 \mathrm{~kg})$ were powdered and exhaustively extracted by maceration at room temperature using EtOH. After filtration, the solvent was removed under reduced pressure, yielding $82.83 \mathrm{~g}$ of crude extract VdE. A total of $3 \mathrm{~g}$ of obtained ethanolic extract was chromatographically separated over Sephadex LH- $20^{\circ}$ and eluted with methanol to afford seven fractions based on their TLC behavior. Fraction $3(80 \mathrm{mg})$ was chromatographed over a reverse-phase ODS cartridge and then purified by preparative RPHPLC $\left[\mathrm{CH}_{3} \mathrm{OH}-\mathrm{H}_{2} \mathrm{O}-\mathrm{CH}_{3} \mathrm{COOH}(50: 49.9: 0.1 \mathrm{v} / \mathrm{v} / \mathrm{v})\right]$ to yield fractions $1(10 \mathrm{mg})$ and $3(8.0 \mathrm{mg})$. Fraction $5(30 \mathrm{mg})$ was also purified by preparative RP-HPLC $\left[\mathrm{CH}_{3} \mathrm{OH}-\mathrm{H}_{2} \mathrm{O}-\mathrm{CH}_{3} \mathrm{COOH}(50: 49.9: 0.1 \mathrm{v} / \mathrm{v} / \mathrm{v})\right]$ to yield fraction $2(6 \mathrm{mg})$. The spectral data of all isolated flavones are in agreement with previously published data and allowed for the identification of $3^{\prime}, 5$-dimethoxy luteolin-7-O- $\beta$-glucopyranoside (1), 5-methoxy luteolin (2) and 3',5-dimethoxy luteolin (3) [13-15].

3',5-Dimethoxy luteolin-7-O- $\beta$-glucopyranoside (1): ${ }^{1} \mathrm{H}$ NMR (400 $\left.\mathrm{MHz}, \delta, \mathrm{CD}_{3} \mathrm{OD}\right): 3.92\left(\mathrm{~s}, 3 \mathrm{H}, \mathrm{OCH}_{3}\right), 3.95\left(\mathrm{~s}, 3 \mathrm{H}, \mathrm{OCH}_{3}\right), 6.61(\mathrm{~s}, 1 \mathrm{H}$, $\mathrm{H}-3), 6.71(\mathrm{~d}, J=2.3,1 \mathrm{H}, \mathrm{H}-6), 6.92(\mathrm{~d}, J=8.4,1 \mathrm{H}, \mathrm{H}-5)$ ), $6.96(\mathrm{~d}, J=$ 2.3, $1 \mathrm{H}, \mathrm{H}-8$ ), 7.47 (d, $J=2.1,1 \mathrm{H}, \mathrm{H}-2$ '), $7.51(\mathrm{dd}, J=2.1$ and $8.4,1 \mathrm{H}$, H-6'), 7-O-Glu 5.1, (d, $J=7.7, \mathrm{H}-1$ ), 3.49-3.52 m; 3.55-3.60 m, 3.65-3.79 m). ${ }^{13} \mathrm{C}$ NMR $\left(100 \mathrm{MHz}, \delta, \mathrm{CD}_{3} \mathrm{OD}\right): 56,6\left(3^{\prime}-\mathrm{OCH}_{3}\right), 56,6\left(5-\mathrm{OCH}_{3}\right)$, 62,6 (C-6"), 71.5 (C-4"), 74.8 (C-2"), 77.9 (C-5") 97.7 (C-8), 98.6 (C-6), 100.4 (C-1"), 107.0 (C-3), 110.4 (C-2'), 116.8 (C-5”), 122.0 (C-1'), 149.6 (C-3'), 152.3 (C-4'), 160.8 (C-9), 162.0 (C-2), 164.2 (C-7), 173.2 (C-4).

5-Methoxy luteolin (2): ${ }^{1} \mathrm{H}$ NMR $\left(500 \mathrm{MHz}, \delta, \mathrm{CD}_{3} \mathrm{OD}\right): 3.85$ (s, $\left.3 \mathrm{H}, 5-\mathrm{OCH}_{3}\right), 6.39(\mathrm{~d}, J=1.75,1 \mathrm{H}, \mathrm{H}-6), 6.43(\mathrm{~s}, 1 \mathrm{H}, \mathrm{H}-3), 6.48(\mathrm{~d}, 1 \mathrm{H}$, $J=1.75, \mathrm{H}-8), 6.86$ (d, $J=8.5,1 \mathrm{H}, \mathrm{H}-5$ '), 7.27 (d, 1H, $J=2.0, \mathrm{H}-6$ '), 7.29 br s, $\left.1 \mathrm{H}, \mathrm{H}-2^{\prime}\right)$.

3',5-Dimethoxy luteolin (3) ${ }^{1} \mathrm{H}$ NMR (400 MHz, $\delta$, Pyridine- $d_{5}$ ): $3.79\left(\mathrm{~s}, 3 \mathrm{H}, \mathrm{OCH}_{3}\right), 3.85\left(\mathrm{~s}, 3 \mathrm{H}, \mathrm{OCH}_{3}\right), 6.74(\mathrm{~d}, J=2.0,1 \mathrm{H}, \mathrm{H}-6), 6.98$ (d, $J=2.0,1 \mathrm{H}, \mathrm{H}-8), 6.98$ (s, 1H, H-3), 7.25 (d, $J=8.3,1 \mathrm{H}, \mathrm{H}-5$ '), 7.57 (m, $\left.1 \mathrm{H}, \mathrm{H}-2^{\prime}\right), 7.62\left(\mathrm{dd}, J=2.1\right.$ and $\left.8.3,1 \mathrm{H}, \mathrm{H}-6{ }^{\prime}\right) .{ }^{13} \mathrm{C} \mathrm{NMR}(100 \mathrm{MHz}$, $\left.\delta, \mathrm{CD}_{3} \mathrm{OD}\right): 56.1\left(\mathrm{OCH}_{3}\right), 56.2\left(\mathrm{OCH}_{3}\right), 96.6(\mathrm{C}-8), 107.8(\mathrm{C}-3), 110.1$ (C-2'), 117.0 (C-5'), 120.7 (C-1'), 151.7 (C-4'), 160.6 (C-2), 161.9 (C-5).

Luteolin (4) ${ }^{1} \mathrm{H}$ NMR $\left(500 \mathrm{MHz}, \delta\right.$, DMSO- $\left.d_{6}\right): 6.24(\mathrm{~d}, J=2.0,1 \mathrm{H}$,
H-6): 6.47 (d, $J=2.0,1 \mathrm{H}, \mathrm{H}-8), 6.57(\mathrm{~s}, 1 \mathrm{H}, \mathrm{H}-3), 6.89(\mathrm{~d}, J=9.0,1 \mathrm{H}$ H-5'), 7.40 (dd, $J=3.0$, and 9.0, 1H, H-6'), 7.43 (d, $J=3.0,1 \mathrm{H}, \mathrm{H}-2^{\prime}$ ).

\section{In vitro schistosomicidal assay}

The LE (Luis Evangelista) strain of S. mansoni was maintained by passage through Biomphalaria glabrata snails and Balb/c mice at the Parasitology Research Laboratory, the University of Franca [16]. After eight weeks, adult $S$. mansoni worms were recovered under aseptic conditions from mice previously infected with 200 cercariae by perfusion of the livers and mesenteric veins [17].

The worms were washed in Roswell Park Memorial Institute (RPMI) 1640 medium (Invitrogen), maintained at pH 7.5 with $20 \mathrm{mM}$ HEPES, and supplemented with penicillin (100 UI/mL), streptomycin $(100 \mu \mathrm{g} / \mathrm{mL})$, and $10 \%$ bovine fetal serum (Gibco). After washing, two adult worms were transferred to each well of a 24 -well culture plate containing $2 \mathrm{~mL}$ of the same medium and incubated at $37^{\circ} \mathrm{C}$ in a humid atmosphere containing $5 \% \mathrm{CO}_{2}$ prior to use. At $24 \mathrm{~h}$ after incubation, the ethanolic extract (VdE), isolated compounds 1-3 and luteolin 4 were dissolved in dimethyl sulfoxide (DMSO) and added to the RPMI 1640 medium to yield respective final concentrations of $12.5,25,50$ and $100 \mu \mathrm{g} / \mathrm{mL}$ or $\mu \mathrm{M}$. The parasites were kept for 4 days and monitored every $24 \mathrm{~h}$ to evaluate their general condition.

The movement was examined by visual inspection using an inverted microscopy and the worms were considered dead when no movement was observed for at least $2 \mathrm{~min}$ of examination and no movement at the other observation time points was detected [18]. After the observation, the culture medium was removed and added fresh culture medium without substance and the motility re-examined up to 24 horas to confirm the mortality. Quadruplicate measurements were recorded for each concentration, and three independent experiments were performed. RPMI 1640 medium and RPMI 1640 with $1 \%$ DMSO (the highest concentration of drug solvent) were used as negative control groups. Praziquantel (PZQ) at $12.5 \mu \mathrm{M}$ was used as a positive control group.

Data were statistically analysed by one-way analysis of variance followed by Dunnet's comparison. The statistical tests were performed with the aid of the Graphpad Prism (version 5.0) software.

All experiments were authorized by the Ethics Committee for Animal Care of the University of Franca (protocol number 028/12), and they were carried out in accordance with the national and international accepted principles for laboratory animal handling and care.

\section{XTT-based cytotoxicity assay}

Cytotoxicity was measured using an in vitro Toxicology Colorimetric Assay Kit (XTT; Roche Diagnostics) according to the manufacturer's instructions. XTT reduction occurs extracellularly on the surface of the plasma membrane via transmembrane electron transport [19] and was originally described for the evaluation of tumor cell line sensitivity to chemicals.

The method is widely used for the quantitative determination of cell proliferation or the cytotoxic effects of chemicals [20]. Chinese hamster lung fibroblasts (V79 cells) were used for the cytotoxicity experiments. The cell line was cultured in HAM-F10 (Sigma-Aldrich) and DMEM (Sigma-Aldrich) (1:1) culture medium supplemented with $10 \%$ fetal bovine serum (Nutricell), antibiotics $(0.01 \mathrm{mg} / \mathrm{mL}$ streptomycin and $0.005 \mathrm{mg} / \mathrm{mL}$ penicillin; Sigma-Aldrich), and $2.38 \mathrm{mg} / \mathrm{mL}$ HEPES (Sigma-Aldrich) at $37^{\circ} \mathrm{C}$ and $5 \% \mathrm{CO}_{2}$. For these experiments, the cells $\left(10^{3}\right.$ cells/well $)$ were plated onto 96 -well microplates, and each 
Citation: Pimenta LP, Kellner Filho LC, Liotti RG, Soares MA, Aguiar DP et al. (2015) In Vitro Antischistosomal Activity and Cytotoxicity of 5-Methoxylated Flavones fom Vochysia divergens, a Flood-Adapted Species from Brazilian Pantanal. Adv Pharmacoepidemiol Drug Saf 4: 182. doi:10.4172/2167-1052.1000182

Page 3 of 5

well received $100 \mu \mathrm{L}$ of culture medium. Twenty-four hours after seeding the cells, culture media containing the tested concentrations of compounds 1-4 dissolved in 0.5\% DMSO were added.

The concentrations tested ranged from 2.6 to $8741.3 \mu \mathrm{M}$ The negative (without treatment), solvent $(0.5 \% \mathrm{DMSO})$ and positive $(25 \%$ DMSO) controls were included.

After incubation at $37^{\circ} \mathrm{C}$ for $24 \mathrm{~h}$, the medium was removed and the cells were washed with $100 \mu \mathrm{L}$ PBS (phosphate buffered-saline). The cells were then exposed to $100 \mu \mathrm{L}$ of HAM-F10 medium without phenol red. Then, $20 \mu \mathrm{L}$ of XTT was added to each well, and the microplates were covered and incubated at $37^{\circ} \mathrm{C}$ for $17 \mathrm{~h}$. The absorbance of each sample was determined using a multi-plate reader (ELISA -Asys - UVM 340 / Microwin 2000) at a test wavelength of $450 \mathrm{~nm}$ and a reference wavelength of $620 \mathrm{~nm}$.

Cell viability was expressed as a percentage of untreated cells, which served as the negative control group and was designated as $100 \%$. Therefore, the results are expressed as a percentage of the negative control. The $50 \%$ inhibition of cell lines growth $\left(\mathrm{IC}_{50}\right)$ was used as analysis parameter calculated using Prism Graphpad Programme and One-way ANOVA was used for the comparison of the mean $(P<0.05)$. The experiments were performed in triplicate.

\section{Results and Discussion}

The chemical study of $V$. divergens successfully isolated the flavones 3',5-dimethoxy luteolin-7-O- $\beta$-glucopyranoside (1), 5-methoxy luteolin (2) and 3',5-dimethoxy luteolin (3) (Figure 1). Although the flavone luteolin and its derivative luteolin-7-O- $\beta$-glucoside have a wide distribution in the vegetal kingdom, the methoxylated derivatives 1 and $\mathbf{3}$ are rare. To the best of our knowledge, this report is the first to isolate flavones $\mathbf{2}$ and $\mathbf{3}$ from $V$. divergens and from the Vochysiaceae family in general.

Regarding the schistosomicidal assay (Table 1), the incubation of male and female adult $S$. mansoni worms with the ethanolic extract of $V$. divergens at a concentration of $50 \mu \mathrm{g} / \mathrm{mL}$ resulted in a $100 \%$ reduction in motor activity within $24 \mathrm{~h}$ regardless of the parasite gender, but the treatment did not induce mortality at the two assayed concentrations. However, 5-methoxy luteolin (2) caused the death of $25 \%$ of male and female adult $S$. mansoni worms in $24 \mathrm{~h}$ at $100 \mu \mathrm{M}$ and also reduced the

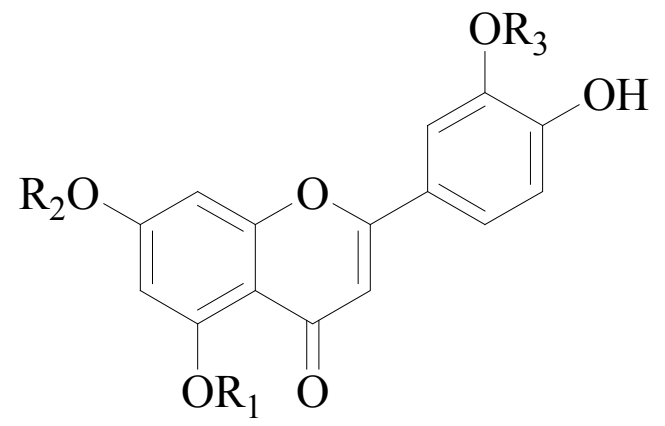

$$
\begin{array}{llll}
\mathbf{1} & \mathbf{R}_{1}=\mathbf{C H}_{3} ; & \mathbf{R}_{2}=\mathbf{G l c} ; & \mathbf{R}_{3}=\mathbf{C H}_{3} \\
\mathbf{2} & \mathbf{R}_{1}=\mathbf{C H}_{3} ; & \mathbf{R}_{2}=\mathbf{H} ; & \mathbf{R}_{3}=\mathbf{H} \\
\mathbf{3} & \mathbf{R}_{1}=\mathbf{C H}_{3} ; & \mathbf{R}_{2}=\mathbf{H} ; & \mathbf{R}_{3}=\mathbf{C H} \mathbf{H}_{3} \\
\mathbf{4} & \mathbf{R}_{1}=\mathbf{H} ; & \mathbf{R}_{2}=\mathbf{H} ; & \mathbf{R}_{3}=\mathbf{H}
\end{array}
$$

Figure 1: Structures of compounds 1-3 from V. divergens and luteolin (4). motor activity by $25 \%$ in $24 \mathrm{~h}$ at $25 \mu \mathrm{M}$ and $50 \%$ at $100 \mu \mathrm{M}$. In addition, luteolin (4) was able to kill $75 \%$ of male and female parasites within $72 \mathrm{~h}$ at $100 \mu \mathrm{M}$ and reduced the motor activity by $75 \%$ under these conditions for male and female adult $S$. mansoni worms.

The other two isolated flavones, $3^{\prime}, 5$-dimethoxy luteolin-7-O- $\beta$ glucopyranoside (1) and 3',5-dimethoxy luteolin (3), showed a slight reduction in their motor activity and the absence of worm mortality. Flavone 3 was more active than $\mathbf{1}$ because it was able to reduce mobility by $25 \%$ only for male worms at a concentration of $12.5 \mu \mathrm{g} / \mathrm{mL}$ at $24 \mathrm{~h}$, whereas flavone 1 presented the same result at $25 \mu \mathrm{g} / \mathrm{mL}$.

To ascertain the cytotoxicity, XTT assays were performed in V79 cells during $24 \mathrm{~h}$ of treatment at concentrations ranging from 2.6 to $8741.3 \mu \mathrm{M}$ for compounds $\mathbf{1 - 4}$. The viability of the cultures was determined, establishing a relationship between the absorbance obtained in the treated and untreated (control) groups as shown in Figure 2.

The treatment of V79 cells with compound 1 resulted in a statistically significant reduction in cell viability at concentrations higher than 656.5 $\mu \mathrm{M}$ when compared to the negative control, whereas treatment with compound 2 showed a statistically significant reduction in cell viability at concentrations above $4166.7 \mu \mathrm{M}$. Conversely, treatment with the compound $\mathbf{3}$ did not result in a statistically significant reduction in cell viability. In contrast, compound $\mathbf{4}$ showed a statistically significant reduction in cell viability at concentrations higher than $136.4 \mu \mathrm{M}$ The $\mathrm{IC}_{50}$ values were $1468.4 \pm 10.5 \mu \mathrm{M}, 5946.6 \pm 2,1 \mu \mathrm{M},>7960.8 \mu \mathrm{M}$ and $270.6 \pm 9.3 \mu \mathrm{M}$ for compounds $\mathbf{1 - 4}$, respectively.

Considering the schistosomicidal activity results of flavonoids 1-3 which share the 2-phenyl-1,4-benzopyrone scaffold, the results related to the isolated 5-methoxy flavones suggest that the exchange of methoxyl group at positions 3' and 7' by hydroxyl groups appears to be important to increase the schistosomicidal activity as observed in more active flavones $\mathbf{2}$ and $\mathbf{4}$. Conversely, the glycosylation at the C-7 position in ring B does not appear to be relevant to the reduction in motor activity in S. mansoni adult worms. Some in vitro studies with natural products have reported that male S. mansoni worms are often more susceptible than female worms [21,22], whereas other studies have not reported any differences between male and female worms $[18,23]$.

In the present study, the flavones $\mathbf{1}$ and $\mathbf{3}$ appear to affect more male than female, this fact can be related to the paring of the male and female which male schistosome ensures the survival of the female by providing protection physical transportation within the vasculature, musculature to aid feeding and other chemo- or thigmatic-maturation factors as well as providing sperm to fertilize the oocyte [24].

Shalaby and co-authors studied the effects of Daucus carota var. boissieri extracts, which have a high content of flavones, including luteolin, on the immune responses of Schistosoma mansoni-infected mice. The anthelmintic activities of the extracts were evidenced via the percent protection, the humoral and cellular immune responses of the mice, as well as the mechanism of immunomodulation [25]. In addition, Kellenberger and collaborators reported that the flavone luteolin is an inhibitor of human enzyme CD38 and its homologous enzyme Schistosoma mansoni $\mathrm{NAD}(+)$ catabolizing enzyme (SmNACE) expressed in Schistosoma mansoni with an $\mathrm{IC}_{50}$ of $8.2 \pm$ $0.2 \mu \mathrm{M}$ and $8.4 \pm 0.4 \mu \mathrm{M}$, respectively [26]. According to Michels et al., 3',5-dimethoxy luteolin (3) and luteolin (4) showed cytotoxic potential in H4IIE rat hepatoma cells ( $30 \%$ reduction after $24 \mathrm{hr}$ at $250 \mathrm{mM}$ ). The differences in sensitivity between several cell lines may be due several 
Citation: Pimenta LP, Kellner Filho LC, Liotti RG, Soares MA, Aguiar DP et al. (2015) In Vitro Antischistosomal Activity and Cytotoxicity of 5-Methoxylated Flavones fom Vochysia divergens, a Flood-Adapted Species from Brazilian Pantanal. Adv Pharmacoepidemiol Drug Saf 4: 182. doi:10.4172/2167-1052.1000182

Page 4 of 5
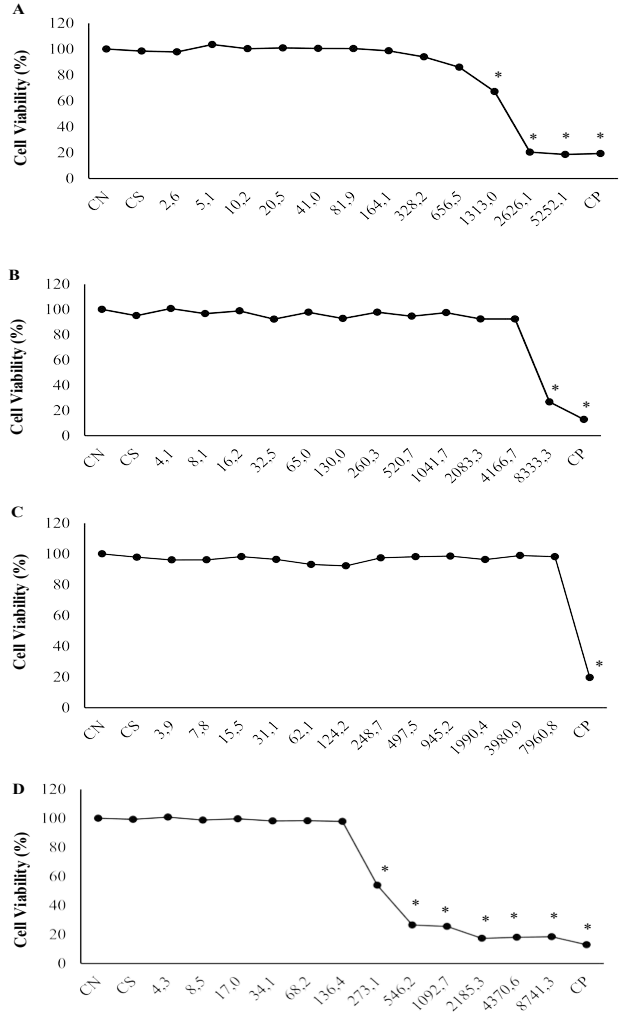

Figure 2: Cell viability of flavones determined by XTT assays in V79 cells: (A) 1, (B) 2, (C) 3 and (D) 4. CN: negative control (without treatment), CS: solvent control (DMSO - $0.5 \%$ dimethyl sulfoxide) and CP: positive control (25\% DMSO). "Statistically different to the negative control group. The IC values were $1468.4 \pm 10.5 \mu \mathrm{M}, 5946.6 \pm 25,1 \mu \mathrm{M},>7960.8 \mu \mathrm{M}$ and $270.6 \pm$ $9.3 \mu \mathrm{M}$ or compounds $1-4$, respectively. factors, among them differences in cellular uptake, export mechanisms or metabolizing enzymes [27].

\section{Conclusions}

In conclusion $V$. divergens is a promising species with which to carry out chemical and biological investigations. The schistosomicidal potential of $V$. divergens has not yet been described in the literature, and further biological studies are required to clarify its schistosomicidal action mechanisms.

\section{Acknowledgements}

The authors are grateful to Fundação de Amparo a Pesquisa do Estado de São Paulo (FAPESP, Grant \# 2013/22030-9; Grant \# 2013/15774-1) and Conselho Nacional de Desenvolvimento Científico e Tecnológico (CNPq) for fellowships. FAPESP (Grant \# 2011/00631-5); FAPEMAT (Grant \# 331950/2012) and INAU are also acknowledged for financial support. The authors also thank Vinicius Palaretti for the NMR spectra.

\section{References}

1. Dalmagro HJ, Lobo FA, Vourlitis GL, Dalmolin ÂC, Antunes JrMZ, et al. (2014) The physiological light response of two tree species across a hydrologic gradient in Brazilian savanna (Cerrado). Photosynthetica 52: 22-35.

2. Neto FC, Pilon AC, Silva DHS, Bolzani VS, Castro-Gamboa I (2011) Vochysiaceae: secondary metabolites, ethnopharmacology and pharmacological potential. Phytochem Rev 10: 413-429.

3. Hess SC, Brum RL, Honda NK, Cruz AB, Moretto E, et al. (1995) Antibacterial activity and phytochemical analysis of Vochysia divergens (Vochysiaceae). J Ethnopharmacol 47: 97-100.

4. Steinmann P, Keiser J, Boss R, Tanner M, Utzinger J (2006) Schistosomiasis and water resources development: systematic review, meta-analysis, and estimates of people at risk. Lancet Infect Dis 6: 411-425.

5. Caffrey CR (2007) Chemotherapy of schistosomiasis: present and future. Curr Opin Chem Biol 11: 433-439.

6. Zhang Y, MacArthur C, Mubila L, Baker S (2010) Control of neglected tropical diseases needs a long-term commitment. BMC Medicine 8: 67-75.

\begin{tabular}{|c|c|c|c|c|c|c|c|c|c|}
\hline \multirow[t]{3}{*}{ Sample } & \multirow[t]{3}{*}{ Incubation period (h) } & \multicolumn{8}{|c|}{$\%$ Reduction in motor activity at a given concentration $(\mu \mathrm{g} / \mathrm{mL}$ or $\mu \mathrm{M})$} \\
\hline & & \multicolumn{2}{|c|}{12.5} & \multicolumn{2}{|c|}{25} & \multicolumn{2}{|c|}{50} & \multicolumn{2}{|c|}{100} \\
\hline & & M & $\mathrm{F}$ & M & $\mathrm{F}$ & M & $\mathrm{F}$ & M & $\mathrm{F}$ \\
\hline \multirow{2}{*}{$V_{d E}^{b}(\mu g / m L)$} & 24 & n.t. ${ }^{a}$ & n.t. & n.t. & n.t. & $100^{*}$ & $100^{*}$ & $100^{*}$ & $100^{*}$ \\
\hline & 72 & n.t. & n.t. & n.t. & n.t. & $100^{*}$ & $100^{*}$ & $100^{*}$ & $100^{*}$ \\
\hline \multirow{2}{*}{$1^{c}$} & 24 & 0 & 0 & $25^{*}$ & 0 & $25^{*}$ & 0 & $50^{*}$ & 0 \\
\hline & 72 & 0 & 0 & $25^{*}$ & 0 & $25^{*}$ & 0 & $50^{*}$ & 0 \\
\hline \multirow{2}{*}{$\mathbf{2}^{\mathrm{c}}$} & 24 & 0 & 0 & $25^{*}$ & $25^{*}$ & $25^{*}$ & $25^{*}$ & $50^{*}$ & $50^{*}$ \\
\hline & 72 & 0 & 0 & 25 & $25^{*}$ & $25^{*}$ & $25^{*}$ & $50^{*}$ & $50^{*}$ \\
\hline \multirow{2}{*}{$3^{c}$} & 24 & 25 & 0 & $25^{*}$ & 0 & $25^{*}$ & 0 & $25^{*}$ & 0 \\
\hline & 72 & 25 & 0 & $25^{\star}$ & 0 & $25^{*}$ & 0 & $25^{*}$ & 0 \\
\hline \multirow{2}{*}{$4^{c}$} & 24 & 0 & 0 & 0 & 0 & $50^{*}$ & $50^{*}$ & $75^{*}$ & 0 \\
\hline & 72 & 0 & 0 & $25^{*}$ & $25^{*}$ & $50^{*}$ & $50^{*}$ & $75^{*}$ & $75^{*}$ \\
\hline \multirow{2}{*}{ Control $^{d}$} & 24 & \multicolumn{2}{|c|}{0} & \multicolumn{2}{|c|}{0} & \multicolumn{2}{|c|}{0} & \multicolumn{2}{|c|}{0} \\
\hline & 72 & \multicolumn{2}{|c|}{0} & \multicolumn{2}{|c|}{0} & \multicolumn{2}{|c|}{0} & \multicolumn{2}{|c|}{0} \\
\hline \multirow{2}{*}{ 1\% DMSO } & 24 & \multicolumn{2}{|c|}{0} & \multicolumn{2}{|c|}{0} & \multicolumn{2}{|c|}{0} & \multicolumn{2}{|c|}{0} \\
\hline & 72 & \multicolumn{2}{|c|}{0} & \multicolumn{2}{|c|}{0} & \multicolumn{2}{|c|}{0} & \multicolumn{2}{|c|}{0} \\
\hline
\end{tabular}

a n.t: not tested.

${ }^{\mathrm{b}} \mu \mathrm{g} / \mathrm{mL}$

${ }^{\mathrm{c}} \mu \mathrm{M}$

${ }^{\mathrm{d}} \mathrm{RPMI} 1640$

$\mathrm{PZQ}$ at $12.5 \mu \mathrm{M}=100 \%$ parasite death after $24 \mathrm{~h}$ of incubation.

${ }^{e}$ Asterisk indicates statistically significant differences compared with the negative control group (RPMI 1640 medium only) ( $\left.p<0.001\right)$.

Table 1: In vitro effects of $\mathrm{VdE}$ ethanolic extract and flavones 1, 2, 3 and 4 on the motor activity of adult $S$. mansoni worms. 
Citation: Pimenta LP, Kellner Filho LC, Liotti RG, Soares MA, Aguiar DP et al. (2015) In Vitro Antischistosomal Activity and Cytotoxicity of 5-Methoxylated Flavones fom Vochysia divergens, a Flood-Adapted Species from Brazilian Pantanal. Adv Pharmacoepidemiol Drug Saf 4: 182. doi:10.4172/2167-1052.1000182

Page 5 of 5

7. Stelma FF, Talla I, Sow S, Kongs A, Niang M, et al. (1995) Efficacy and side effects of praziquantel in an epidemic focus of Schistosoma mansoni. Am J Trop Med Hyg 53: 167-170

8. Botros S, William S, Hammam O, Zídek Z, Holý A (2003) Activity of 9-(S)[3-hydroxy-2 (phosphonomethoxy)propyl]adenine against Schistosomiasis mansoni in mice. Antimicrob Agents Chemother 47: 3853-3858

9. Ribeiro-dos-Santos G, Verjovski-Almeida S, Leite LC (2006) Schistosomiasis-a century searching for chemotherapeutic drugs. Parasitol Res 99: 505-521.

10. Pedroso RCN, Pimenta LP, Lima WC, Soares MA, Magalhães LG, et al. (2012) Schistosomicidal potential of endophytic fungi associated with Vochysia divergens Pohl. Planta Med 78: 1246-1246.

11. Cunha NL, Uchôa CJ, Cintra LS, de Souza HC, Peixoto JA, et al. (2012) In vitro schistosomicidal activity of some Brazilian Cerrado species and their isolated compounds. Evid Based Complement Alternat Med, ID 173614.

12. Bertanha CS, Utrera SH, Gimenez VMM, Groppo M, Silva MLA, et al. (2013) Antibacterial evaluation of Styrax pohlii and isolated compounds. Braz J Pharm Sci 49: 653-658.

13. Osawa T, Sakuta H, Negishi O, Kajiura I (1995) Identification of speciesspecific flavone glucosides useful as chemotaxonomic markers in the genus. Biosci Biotechnol Biochem 59: 2244-2246.

14. Ueli AH, Carl AM, Cecillia MJ, Donald AP (1990) Chrysoeriol and Luteolin Released from Alfalfa Seeds Induce nod Genes in Rhizobium meliloti. Plant Physiol 92: 116-122.

15. Monache GD, De Rosa MC, Scurria R, Monacelli B, Pasqua G, et al. (1991) Metabolites from in vitro cultures of Cassia didymobotrya. Phytochemistry 30 : 1849-1854.

16. Magalhães LG, Kapadia GJ, da Silva Tonuci LR, Caixeta SC, Parreira NA, et al. (2010) In vitro schistosomicidal effects of some phloroglucinol derivatives from Dryopteris species against Schistosoma mansoni adult worms. Parasitol Res 106: 395-401.
17. Smithers SR ,Terry RJ (1965) Infection of laboratory hosts with cercariae of Schistosoma mansoni and the recovery of adult worms. Parasitology 55: 695700 .

18. Manneck T, Haggenmüller Y, Keiser J (2010) Morphological effects and tegumental alterations induced by mefloquine on schistosomula and adult flukes of Schistosoma mansoni. Parasitolology 137: 85-98.

19. Berridge MV, Herst PM, Tan AS (2005) Tetrazolium dyes as tools in cell biology: new insights into their cellular reduction. Biotechnol Annu Rev 11: 127-152.

20. Bernas T, Dobrucki J (1999) Reduction of a tetrazolium salt, CTC, by intact HepG2 human hepatoma cells: subcellular localization of reducing systems. Biochim Biophys Acta 1451: 73-81.

21. Sanderson L, Bartlett A, Whitfield PJ (2002) In vitro and in vivo studies on the bioactivity of a ginger (Zingiber officinale) extract towards adult schistosomes and their egg production. J Helminthol 76: 241-247.

22. De Melo NI, Magalhães LG, De Carvalho CE, Wakabayashi KA, Aguiar GP et al. (2011) Schistosomicidal activity of the essential oil of Ageratum conyzoides L. (Asteraceae) against adult Schistosoma mansoni worms. Molecules 16: 762 773

23. Porto TS, Da Silva Filho AA, Magalhães LG, Dos Santos RA, Furtado NA, et al. (2012) Fungal transformation and schistosomicidal effects of pimaradienoic acid. Chem Biodivers 9: 1465-1474.

24. Fitzpatrick JM , Hoffmann KF (2006) Dioecious Schistosoma mansoni express divergent gene repertoires regulated by pairing. Int J Parasitol 36:1081-1089.

25. Shalaby NM, Maghraby AS, el-Hagrassy AM (1999) Effect of Daucus carota var. boissieri extracts on immune response of Schistosoma mansoni infected mice. Folia Microbiol (Praha) 45: 441-448.

26. Kellenberger E, Kuhn I, Schuber F, Muller-Steffner H (2011) Flavonoids as inhibitors of human CD38. Bioorg Med Chem Lett 21: 3939-3942.

27. Michels G, Mohamed GA, Weber N, Chovolou Y, Kampkötter A, et al (2006) Effects of methylated derivatives of Luteolin isolated from Cyperus alopecuroides in rat H4IIE hepatoma cells*. Basic Clin Pharmacol Toxicol 98 168-172. 